International Journal of Linguistics, Literature and Culture
Available online at https://sloap.org/journals/index.php/ijllc/
Vol. 4, No. 4, July 2018, pages: $103 \sim 111$
ISSN: $2455-8028$
https://sloap.org/journals/index.php/ijllc/article/view/272

\title{
Balian Wara Position of Dayak Lawangan
}

\author{
Tardi Edung a \\ I Nice Yudha Triguna ${ }^{b}$ \\ I Wayan Budi Utama ${ }^{c}$
}

\section{Article history:}

Received: 15 February 2018

Revised: 26 June 2018

Approved: 19 July 2018

Published: 31 July 2018

\section{Keywords:}

Position;

Functions;

Sustainability;

Balian Wara;

\begin{abstract}
Globalization has brought challenges as well as changes in Society. The change was vague, flashy, fast, slow, limited and comprehensive. It has happened to social value shift, social action, social institution arrangement, organization, social stratification, power, and authority. All of them could be changed into a better or worse situation. The social changes have happened because of human creativity which created changing itself toward daily life. Social change has also experienced by Hindus people in Dayak Kaharingan. The change has impacted their religious rituals, as well as their social organization. Nowadays Balian Wara, as a religious ritual leader, is difficult to be found since its small number. In another side, Wara ritual must be done. Therefore, the worry of the future Balian Wara existence has arisen. Cultural value shift phenomena have also been worried since the phenomena will create an identity crisis in the future. At this point, the position of Balian Wara needs to be re-confirmed. Also, the function and existence of Balian Wara in Dayak Lawangan must be studied carefully. That is why this research has been conducted. The confirmation of Balian Wara position was studied through ethnography descriptive approach using the qualitative method. It was conducted by investigating and by finding a solution to the phenomena faced by Hindus Kaharingan nowadays.
\end{abstract}

2455-8028 ${ }^{\circledR}$ Copyright 2018. The Author. This is an open-access article under the CC BY-SA license (https://creativecommons.org/licenses/by-sa/4.0/) All rights reserved.

\author{
Author correspondence: \\ Tardi Edung, \\ State Hindu Religion Institute, \\ Tampung Penyang Palangka Raya, \\ Indonesia, Email address: tardi.edung@yahoo.com
}

\section{Introduction}

Globalisation has brought new change as well new challenge to the world, especially to the developing nations. The development has gone together with science and technology development as well as the society transitional.

\footnotetext{
${ }^{a}$ State Hindu Religion Institute, Palangka Raya, Indonesia

${ }^{\mathrm{b}}$ Hindu University Denpasar, Indonesia

${ }^{c}$ Hindu University Denpasar, Indonesia
} 
They simultaneously go with the development of science and technology information during the period of transition from the traditional society-based to modern industrial society- based. Change movement is felt more quickly and continuously, along with the modernization of the turmoil that afflicting the world. According to Syarbaini and Rusdiyanta (2009:148), modernization is also a form of social change towards the progress of a society and a nation with modernization as a staple feature. It is revolutionary, complicated, global, systematic, long-term, and gradually process. It is also progressive. Douglas and Isherwood (in Abdullah, 2006:169) state that globalization has risen a type of ideology that becomes establishment basis, preservation basis and changes basis in society. They are centered on the process of self-identifying and the establishment of people differences.

Society changes over time. Its change could be vague, nondescript, slow, fast, partial, limited or thoroughly. Change forms can also be in a shift of social values, social behavior, social organization, institutions, social stratification, or power and authority. They can be changed into both better and worse. Social change occurs due to factors of human dynamics. The human creativity creates new conditions and changing, especially in the areas of daily living. The nature of social change is like a chain that involves all aspects of life. Next, social change has also becoming parts of a cultural change since no society without cultural and no culture that does not manifest in society.

Alvin Toffler (in Syarbaini and Rusdiyanta, 2009: 136) stated that social change now undergoing rapidly. It is caused by the progress of science and technology, especially the mass media progress. Social change, as described by Alvin Toffler, has gone through three waves, namely: the traditional agrarian era, the era of industrialization as well as the era of information and communication. Social change experienced by humanity today, by Toffler, is called the "era of modernization". Social changes brought by globalization and modernization that occurred today, have also impacted the communities of Hindus Kaharingan in Dayak Lawangan. In this research, Wara religious rites ritual as sacred religious has also been impacted. The ritual of Wara is a belief system and has become a strong tradition among Dayak Lawangan society that carried out hereditary from generation to generation. Significant changes occurred was on social organization level regarding the availability figure of Balian Wara (following will be mentioned as BW). Nowadays, BW is quite difficult to be found since the numbers are very limited. Serious concerns have arisen in Hindu Kaharingan Dayak Lawangan society, related to the availability figure of BW in future. Also, the concern has also occurred in shift cultural values of the society. This situation leads to the crisis of cultural identity.

According to Maran (2000:15), a human can be defined based on the free definition, but as a cultural being (sentient culture) human is can not be divided from historical fact". As a cultural being, the human is a culture creator. This is an expression form of civilized human existence. This will be continued to establish identity tradition in a small, unpretentious society group. BW is the man who embodies the expression through cultural belief and Wara ritual. BW will continue the tradition in a small group. However, it is questioned whether small amounts of the group will be able to maintain cultural values in future or not.

Hindu Kaharingan Dayak Lawangan is a group of human beings as the creator as well the owner of Culture. To express the existence of humanity, Hindu Kaharingan in Dayak Lawangan carries Wara as a religious rites ritual. The ritual is served by BW. Based on the changes and concerns that have been mentioned above, It is important and needed to be examined in order to obtain solutions about the availability figure of BW as the one who will carry religious rites ritual of Wara. The availability of BW has been a problem among Hindu Kaharingan tribe Lawangan, Dayak. As Wara ritual is ancestral heritage and cultural/ religious belief system, this ritual must be kept doing. Furthermore, as Wara tradition has also been a part of norms, values, mores, and social rules, it must be implemented in the social environment where Wara religious culture has been created. In order to find a solution to the phenomena mentioned above, this study must be conducted. The main purpose of conducting this study is to find out how is the position of the BW in Hindu Dayak Lawangan nowadays, How are its function and its sustainability in the future. The targeted research findings are hoped to be a solution, especially in preserving and maintaining the existence of beliefs, cultures, and customs.

\section{Research Methods}

This is an ethnography study that was conducted using the descriptive qualitative method. The ethnography study itself can not be divided with the descriptive qualitative method. The researchers completely immersed themselves in the lives, culture, and situation being studied. In other words, The researchers lived together with Hindus people in Dayak Lawangan and are contacted every day. During the process, the researchers joined all religious rituals, especially Wara rituals and then made a lot of interviews with the people in Dayak Lawangan. After 
that, the researchers described what was seen dan studied about BW and situation faced by Hindus people. The description was made in a qualitative approach.

\section{Results and Analysis}

The culture according to Koentjaraningrat (1985: 180) is "the whole system of ideas and human beings work results in the framework of social life, which belongs to the human by learning". Koentjaraningrat (2004: 2-3) also stated that the content of culture consists of religious systems, religious ceremonies, civic organizations, livelihoods, systems of knowledge, language, arts, technology systems, and equipment. This means culture is something complete with a variety of elements that supporting and complementing each other. Based on that meaning and cultural content, it is concluded that the religious system of religious ceremonies is a very difficult and slow to be influenced in comparison with other elements. Nowadays, religious and ritual ceremonies elements of Wara needs to be reconfirmed as a part of religion as well culture in society. As an idea at the same time the work of humans in order to meet the necessities of life, then the ritual of Wara until recently by a Hindu Kaharingan Dayak Lawangan is still very strongly held religious beliefs, and as having been affecting pattern thinking and viewpoints in the life of society.

While the Tylor (Wiranata, 2002: 95) defined culture as follows; "Culture is a complex, which contained knowledge, belief, art, morals, law, custom, and any other capabilities and habits that it may by man as a member of society". Culture in the Kamus Besar Bahasa Indonesia (2008: 214) is defined as 1) activities and the creation of the inner (mind) of man (arts, beliefs, customs), 2) anthropological, it is the overall knowledge of human as social beings that used to understand environment as well the experiences and become a guideline of human action.

Next, Kamus Besar Bahasa Indonesia defines (2008: 1556) Wara as information or announcements. According to the understanding in the society, and based on oral traditions context learning, "Wara" is understood as a word derived from "Ngewara" which means "Ngengkulek" or "Nyengkulek". Ngengkulek or Nyengkulek generally could be interpreted as notice or notify. Based on the explanation, it is understood that BW is the one who has to inform about Liau and Ju'us journey process of a person who has passed away. The information is told in Wara Ritual. Wara Ritual ceremony of death is held by Hindus Kaharingan Dayak Lawangan. In other words, BW serves Wara ritual in order to inform the process of Ju'us and Liau returning journey to the place of their origin. It is a must in order to give the Holiness and perfection of eternal union with The Creator.

Wara ritual performed is inseparable from BW role. He is a figure with special skill and ability to utter some spells and Balian sacred songs. Sacred songs of Balian are sung by Betinga in the Religious Ritual sermon process of Wara (death). As the BW Tuha (The leader of Wara) leads ritual serving, BW Penuing (The vice leader of Wara) will answer some utterance of BW Tuha utterance. The mantra and holy shlokas verses will remind Ju'us and Liau death about who he/ she actually is. Furthermore, Madrasuta (2013: 6) mentions that mantra, shloka / the holly song, and self-remembrance will become very useful for the dead souls on his/ her journey. The holy song becomes a valuable aid for those who have passed away since the song is a part of religious teaching. The songs or mantras are like a radio transmitter that transmits vibrations song, as well as prayers and good thoughts. The vibrated songs vibrated prayers, and good thought will reach the souls of the dead. The implementation of Wara ritual in Hindus Kaharingan Dayak Lawangan social life has been a tradition from generation to generations. Hindus Kaharingan Dayak Lawangan totally believes that Wara is an ancestral tradition.

\subsection{The Position of The Balian Wara Dayak Lawangan}

The position is a particular way in which the status of someone or something is placed or arranged. Status is the social position of the individual in a social group or a degree from a group compared to other groups. In other words, status is the position of affairs at a particular time, especially in social or political contexts. According to Soekanto (2009: 210-211), social status or position is the relative rank that an individual holds, with attendant rights, duties, and lifestyle, in a social hierarchy based upon honor or prestige. The status is as follows: 1) Ascribed status; Ascribed status is the social status in which a person is assigned at birth or assumed involuntarily later in life. It is a position that is neither earned nor chosen but assigned. This position is retrieved because of the birth. 2) Achieved status; Achieved status is a concept developed by the anthropologist Ralph Linton denoting a social position that a person can acquire on the basis of merit; it is a position that is earned or chosen. It is the opposite of ascribed status. It reflects personal skills, abilities, and efforts. The position is opened to all members of the society. Each individual

Edung, T., Triguna, I. B. Y., \& Utama, I. W. B. (2018). Balian Wara position of Dayak Lawangan. International Journal of Linguistics, Literature and Culture, 4(4), 103-111. https://doi.org/10.21744/ijllc.v4n4.272 
in society can achieve it, based on personal skill. The last is signed status. It is a position given by a group or groups to someone who is meritorious to the community.

Next, the position can be distinguished into two types. First, position in a small community. Second, the position in a society that is already complex since the position is in a big community. These two kinds express the position/status of a person in a social environment. This is very important.

The position of the BW, theologically, is a critical reflection of faith that can be accountable rationally. According to Saidi (2004: 277) "oral tradition" on the Ngaju Dayak society, has been a source of religious understanding. The sources are in the form of sacred literature and spiritual paintings. Sacred literature is divided into three parts, namely: 1) sacred songs, 2) Balian songs and 3) songs of Balian and literary tradition. Scharer stated that the most important thing in the religious knowledge worldview in profane. It implies the totality of religious life in Dayak society. It means, theologically, BW position is trusted as a religious ritual that given orally from generation to generations. While the source of Godly understanding in Hindus Kaharingan Dayak Lawangan is from sacred songs, songs of Balian, holy literature, and paintings.

Sociologically, knowledge or nature understanding, behavior, and social development are associated with social structures, social processes, and social change. The position of $\mathrm{BW}$ in religious sermons, sociologically, is as follows: 1) Giving an overview of Wara rituals clearly. This is important to be spiritual guidance for Hindus Kaharingan Dayak Lawangan; 2) Overseeing, controlling and distributing all abilities and desires of Hindus Kaharingan Dayak Lawangan; 3) Representing Hindus Kaharingan Dayak Lawangan in conducting the Wara ritual ceremony.

Psychologically, science that deals with mental processes both normal as well abnormal, and its influence on behavior, or symptoms and mental activity are held by BW. The position of BW is important as the human illusion has been implemented into religion as the result of humanity worries. Human is afraid of disaster and other troubled. Therefore they create religion as something important, so they can be escaped from disaster. That is why BW for Hindus Kaharingan Dayak Lawangan is important. Psychology and religion have a strong relationship with mental health. As Hindus Kaharingan Dayak Lawangan surrender to the highest power of God, their soul will have peaceful. Soul feels peace after conducting religion rituals.

In anthropology, sciences about human origins deal with the variety of color, physical form, customs, and beliefs of the past. Specifically, cultural anthropology is the science of human that studied from historical culture. Cultural anthropology of BW position views Wara as an ancestral heritage which has been spoken through the oral tradition from generation to generations. BW delivers a speech about the origins of human life, as well as informing processes of human death in returning journey. This was done through Wara ritual. Wara ritual itself is an oral tradition that believed and done in the belief system. The system is revealed in action, in activities, and in the cultural community of Hindus Kaharingan Dayak Lawangan life. The implementation of Wara religious rituals ceremony can only be done when Balian Wara figure has been available.

BW also has got his rights, namely: receiving Upa Paleh Temay Temayen, determining and choosing Penuing as well Pengading Wara Balian, deciding to stop or to continue Betinga, and getting another award. Beside having rights, The BW has also got some obligations such as giving service to the people who need, dividing the Upa Paleh Temay Temayen, reminding and carrying out the ritual of Ngater Ngater and Kelangkang Osok, and providing some learning and training to younger generations. The role of BW is: guiding Liau and Ju'us, from "Melinang Bungut Melinang Datai" to "Mosses Turu Tuntung Peyuyang Turu Tengkang". Kelelungan towards "Usuk Tolang Nyoron Bawon Senangkai", and after being purified it will be "Aning Kelelungan Kelelio God" that is to be united with the Creator/ Almighty God.

Based on the above description, the position of the BW Dayak Lawangan is as clergy or a religious ceremony leader. The position is achieved due to his own efforts, not on the basis of birth. This kind of religious clergy or spiritual leader position is opened to Hindus Kaharingan Dayak Lawangan. As a spiritual leader who leads Wara ritual ceremony in the society of Hindu Kaharingan Dayak Lawangan, BW keeps holding norms and laws. This is very important since the position of BW is obtained through his own works, that is keeping norms and laws strictly. This kind of position has also gained recognition in the social life. People around will admit BW position in the community since his efforts have been gained through his own efforts.

\subsection{The Function of The Balian Wara Dayak Lawangan}


Function according to Merton ( in Ritzer, 2007: 22) is: "the effects can be observed towards the adaptation or adjustment in a system". Gie (in Waloyu and Wirawan, 2002: 73) stated function as a group activity that belongs on the same kind of based in their nature. Next, based on Kamus Besar Bahasa Indonesia defines (2008: 400) function means 1) Position (job) done, 2) Faal (body part works), 3) related Quantity. 4) Utility and 5) element of a language. According to Spiro (in Koentjaranigrat, 2002: 212-213), a book entitled "A Typology of functional analysis", mentions three ways of function usage: 1) Implementation as a relationship between something. 2) The explanation of the relationship between correlations of one thing with another. 3) Usage describing the relationship between one thing with the other things in an integrated system.

The word 'function' in the social life is a usability thing for a social life; this function is related to the institution in a society which has a very important meaning for the survival of the community concerned. A social institution in the community is used to persist in an orderly manner. The manifest function has been realized by society. According to Robert k. Merton (Ritzer, 2007: 24) the manifest functions are clear and known by people and latent functions that hidden and not known by the people.

The institution, according to Wiranata (2002: 74), is a social structure in which people cooperate and which influences the behavior of people and the way they live. An institution has a purpose. Institutions are permanent, which means that they do not end when one person is gone. The institution is a system of social behavior. Whether the institution good or not is seen through how the institution itself give contributions to social life or not. The balance between man and nature will be realized by togetherness setting in a community. It is believed together that nature is the source of life for human; therefore nature needs to be preserved. The awareness of the attitudes in respecting and maintaining natural must be kept.

Dhavamony (2010: 150) stated that a sacred tradition or the mythology of a society is a group of stories about people's culture. It determines the applicable rite as a map of social rules, or as a fixed model of moral behavior. BW serves to organize the ceremony of Nempasuk Bangkei Tong Suang Lungun Atawa Tabala, and Ngelebeng ceremony. The function of BW activities is to do sermons of Ngokoi Okan Liau, Jemamo, Ngepe, Kelulangan, Pedolui Liau Ngater Liau, Nempuk Kelelungan, Tempun Tempusan-Ngene, Selepaket, Ngapek Nguew, Boyas Ngejujus, Мипи. The function of social institutions is to carry out customary law bolum and customary law Mate through the implementation of Paner Rena Surah Suntoh or Paner Jampa Tarung Sundang (Customary Council) which is implemented by Pengulu and Mantir. Social functions create a balance between human through solidarity and togetherness. Human and nature can be balanced through the implementation of Wara ritual. It is done to clean nature as well to keep the balance of the universe due to the influence of Pali Pulan death. Through the implementation of Saki Palas Tana, and through the implementation of Balian Nyapu Ipar, human will remember The Creator and surrender totally to The Creator.

BW also serves to regulate many things since it has got knowledge and understanding of rules and procedures for doing religious rituals of Wara. The function of activities is to carry out ceremonies in accordance with the rules that have been conducted from generation to generations. Related to cultural and religious social institutions in carrying out the ritual of Wara, customary law has become an important part. It is a rule that has been steady customing for organizing actions. A social function BW toward the life of Hindu Kaharingan Dayak Lawangan is to carry out Wara religious rituals ceremony. The BW is the one who will deliver the testimony of belief towards all people and also continue the culture of their ancestors. A sacred tradition or the mythology of a society is a group of stories that told to people in order to deliver testimony about the belief system and to determine the applicable Rite as a map of social rules. It is also a fixed model that set people behavior and morals in society. Based on what have been explained above, it is simply stated that BW function is to conduct the religious ceremony of Wara ritual for Hindu people in Dayak Kaharingan.

\subsection{Balian Wara Sustainability towards Hindus Dayak Lawangan}

'Word Commission on Environment and Development' proposed sustainability as a concept of an ethical, timeoriented set of principles and views. According to Kamus Besar Bahasa Indonesia (2008: 786), sustainability means process, means, things that go continually. In general, sustainability is an endurance of a system and process. Sustainability in the context of history is an ongoing series of events. This means human life today is a chain of past and present life. Every event is not independent and separate from other events. Hindus sustainability (Nirvana) are: 1) the Hindu term of circumstance and perfect tranquility for every being due to the world end and rebirth 2) the

Edung, T., Triguna, I. B. Y., \& Utama, I. W. B. (2018). Balian Wara position of Dayak Lawangan. International Journal of Linguistics, Literature and Culture, 4(4), 103-111. https://doi.org/10.21744/ijllc.v4n4.272 
place of freedom/perfection. It is a continual process or a continuous way, to maintain a set of future-oriented principles and endurance views.

Those who perform good life in this worldly life will be united with their ancestors in Pitri-loka. As for those who stop doing Sradha and religious rituals due to bad influence, ignorance and selfishness will be greatly injured by the ancestors. By conducting ceremonies to gain ancestors grace by carrying religious rituals and worship regularly, will gain grace and virtue of life. Implementation must refer to the definition of values or norms itself, then that should be maintained is a system of values and belief systems that must be sacred. The values of sacredness need to be kept in mind in every ceremony so that the sacred religious does not change with profane values because of the social changes that occur.

The sustainability of Balian Wara is very dependent on the way used by the Hindu Kaharingan community of the Dayak Lawangan tribe to maintain the existence of the Wara ritual continuously to maintain the principle and identity. The ritual of Wara is an ongoing history of Hindu Kaharingan life in Dayak Lawangan. It cannot stand alone. It is not apart from the death of Mung Munur ancestor. Therefore Wara is the implementation of the religious ceremonies that have become one with cultural systems in Dayak Lawangan society. As culture is created by human, it is always changed as science and technology are also change. . Sustainability of BW is inseparable from the culture that flourished in Hindu society of Dayak Lawangan Kaharingan. It has been a whole knowledge and social understanding to maintain BW existence and Wara ritual. The opinion is the same as what has proposed by I.B Mantra (1996: 7). He stated that wisdom of the whole existing cultural traditions potential must be improved and be developed in all human aspects.

It can be improved and developed through cultural study and tracking made by religious figures, traditional customs figures, and young generation of Hindu Kaharingan Dayak nowadays. Next, by implementing the adaptive system. An adaptive system is a process to change the individual at a time in response to changes in the environment that affect the integrity or wholeness. The environment is all over the conditions or circumstances that affect the development of an organism or group of organisms that are present in the environment. BW has become vital since religious activity is a necessity to display religious identity. Ritual of Wara which has become a necessity in religious practice needs to be done to create stability. Sustainability of BW must be maintained by making improvements and continuous regeneration. Next, it is a must to prepare a competent future BW, by providing learning and training to young people who have the ability and talent. By doing this, all young people have got the same chance to be BW in order to keep the identity of BW figure in Wara ritual.

The figure is the fundamental need. Based on the belief system of Hindu Kaharingan Dayak Lawangan, Wara ritual must be done or the death will stay in human life and make many problems in living family members. If someone who has died can get Wara ritual, then Liau can provide peace and happiness for family members. For Hindu Kaharingan Dayak Lawangan, conducting religious rites ritual of Wara means conducting mandate from their ancestors (Ngingat Budi Tiwey Diran Bases, Ulun represents one Month Bayuh Taun Alem). Efforts are being made to maintain the sustainability of the BW i.e. developing patterns of oral traditions in teaching and training, and finding and mentoring good $\mathrm{BW}$ candidate/ $\mathrm{BW}$ future. This can be made through improvements in the quality of human resources i.e. to increase knowledge and understanding of religion and culture. The figures who will become

BW are individuals who have the desire to maintain integrity and trust and culture, as well as qualified i.e. capable of Betinga independently and then conducting the process of Ngawit Nginte and Betumang (learning). Based on the needs and the efforts made by the people of Hindu Kaharingan Dayak Lawangan, sustainability of BW will continue to exist.

\section{Conclusion}

Theologically, psychologically, sociologically, and anthropologically, the position of BW is an active action with many duties. The BW has to choose and mentor a new BW candidate. The role of $\mathrm{BW}$ is to give religious services at the special ritual of Wara. Therefore, the position of BW in social life is as "Clergy" to the conducting Wara religious rites ritual. The functions of the BW are: to set in death rituals, to conduct Wara rituals, to carry religion and culture duties, and to carry out the customary law as a function of the social institution. It has also balance function, that is to construct harmony between human to human, human to the universe and human to The Creator. Therefore, it is said that BW is very important as it implements belief system that is acted in religious ceremony rituals for Hindu Kaharingan Dayak Lawangan. Based on the needs and efforts of maintaining the sustainability of the Balian Wara conducted by a Hindu Kaharingan society in Dayak Lawangan, then the sustainability of BW will continue unabated since the belief system has been real in the social life. 
Conflict of interest statement and funding sources

The authors declared that they have no competing interest. The study was financed by personal funding.

Statement of authorship

The authors have a responsibility for the conception and design of the study. The authors have approved the final article.

\section{Acknowledgments}

The authors would like to thank the editor of IJLLC for their support, advice, and valuable time. 


\section{References}

Abdullah, F. (2006). Measuring service quality in higher education: HEdPERF versus SERVPERF. Marketing Intelligence \& Planning, 24(1), 31-47.

Abdullah, I. (2006). Dekonstruksi Komunitas: Dari Homogenitas Nilai ke Diferensiasi Praktik Sosial. Dalam Konstruksi dan Reproduksi Kebudayaan. Yogyakarta: Pustaka Pelajar.

Alam, B. (2014). Globalisasi dan perubahan budaya: perspektif teori kebudayaan. Antropologi Indonesia.

de Wolf, J. J. (2002). Conditions of comparison. Anthropology, by Comparison, 95.

Dhavamony, M. (1995). Fenomenologi agama. Kanisius.

Dhavamony, M., \& AYDIN, F. (2010). DINLERDE TANRI ANLAYIŞI. Sakarya Üniversitesi İlahiyat Fakültesi Dergisi, 12(22).

Indonesia, P. R. (2003). Undang-undang Republik Indonesia nomor 20 tahun 2003 tentang sistem pendidikan nasional. Jakarta: Pemerintah Republik Indonesia.

Koentjaraningrat, \& Koentjaraningrat. (1991). Metode-metode penelitian masyarakat. Gramedia Pustaka Utama.

Koentjaraningrat. (1957). A preliminary description of the Javanese kinship system (Vol. 4). Yale University, Southeast Asia Studies.

Koentjaraningrat. (1961). Some Social-anthropological Observations on" gotong Rojong" Practices in Two Villages of Central Java. Cornell univ..

Madrasuta, N. M. (2006). Semua Agama Tidak Sama. Medan: Media Hindu.

Mantra, I. B. (1996). Landasan Kebudayaan Bali. Yayasan Dharma Sastra.

Maran, A., Crepaldi, C., Trupiani, S., Lucca, T., Jori, E., Macdonald, I. A., ... \& Del Prato, S. (2000). Brain function rescue effect of lactate following hypoglycaemia is not an adaptation process in both normal and type I diabetic subjects. Diabetologia, 43(6), 733-741.

Pendidikan Nasional, D. (2008). Kamus Besar Bahasa Indonesia, edisi keempat. Jakarta: Gramedia Pustaka Utama.

Ritzer, G. (2007). The Blackwell encyclopedia of sociology. Mathematical Monthly, 107(7), 615-30.

Rusdiyanta, S. S. (2009). Dasar-dasar sosiologi. Penerbit Graha Ilmu. Yogyakarta.

Saidi, A. (2004). Menekuk agama, membangun tahta: Kebijakan agama Orde Baru. Depok: Desantara.

Saidi, S. A., Holland, C. M., Kreil, D. P., MacKay, D. J., Charnock-Jones, D. S., Print, C. G., \& Smith, S. K. (2004). Independent component analysis of microarray data in the study of endometrial cancer. Oncogene, $23(39), 6677$.

Soekanto, S. (2009). Teori Peran.

Soekanto, S. (2009). Sosiologi Suatu Pengantar Edisi 1. Jakarta [ID]: Grafindo. Tafalas M. 2010. Dampak pengembangan ekowisata terhadap kehidupan sosial dan ekonomi masyarakat lokal. Studi kasus ekowisata bahari Pulau Mansuar Kabupaten Raja Ampat (Doctoral dissertation, Tesis]. Bogor [ID]: Institut Pertanian Bogor).

Spradley, J. P., Elizabeth, M. Z., \& Amirudin. (1997). Metode etnografi.

Syarbaini, S. (2009). Rusdiyanta. Dasar-dasar Sosiologi. Yogyakarta: Graha Ilmu.

Wiranata, I. G. A. (2011). Antropologi Budaya. Citra Aditya Bakti. 


\section{Biography of Authors}

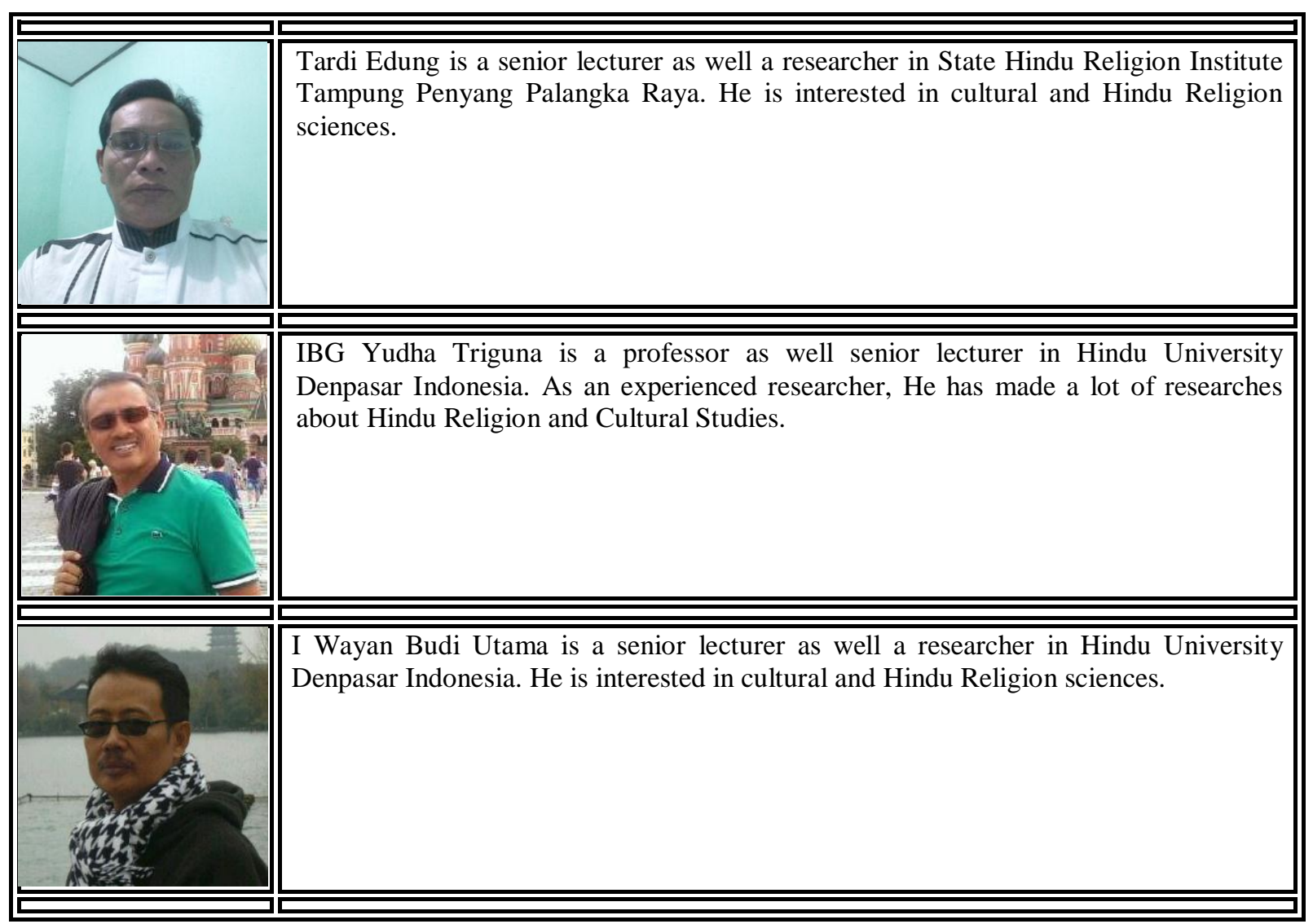

